\title{
Exploring the Factors Affecting Consumer Purchase Behavior during COVID-19: A Case Study of Techno Products in Dhaka City
}

By Takrima Jannat, Syed Abdullah Al Noman, Anika Meher Amin, Md. Shafkat Imon Araf, Md. Irtija Tahmid Hossain \& Siha Fatima Hoque Bangladesh University of Professionals Abstract- Purpose: This paper proposes an exhaustive examination of investigating the variables influencing shopper/consumers' buy conduct during COVID-19 on techno items in Dhaka city. This study intends to investigate the components emerging from vulnerability like Covid pandemic on the customer buy conduct of techno items in Dhaka city.

Methodology: 226 respondents were surveyed using a 19- items structured questionnaire. Exploratory Factor Analysis technique was used to identify the significant factors.

Findings: Results demonstrated that five factors, namely, economic fluctuation and technological value chain, e-commerce wave, digital workplace/force, crisis attitude, motivations of changing consumer behavior were found significantly responsible for influencing shopper/consumers' buy conduct during COVID-19 on techno items in Dhaka city.

Keywords: covid-19, consumer behavior, technology industry, economy fluctuation.

GJMBR-E Classification: JEL Code: M37

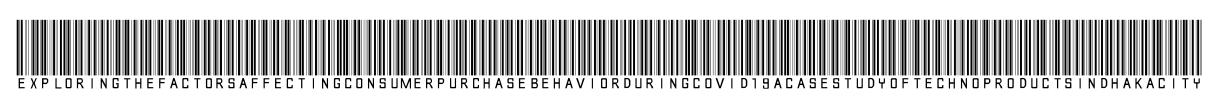

Strictly as per the compliance and regulations of:

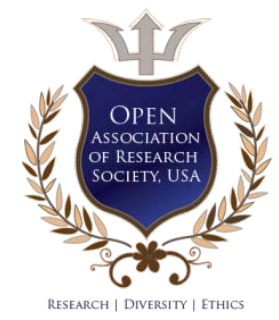

(C) 2021. Takrima Jannat, Syed Abdullah Al Noman, Anika Meher Amin, Md. Shafkat Imon Araf, Md. Irtija Tahmid Hossain \& Siha Fatima Hoque. This is a research/review paper, distributed under the terms of the Creative Commons Attribution-Noncommercial 3.0 Unported License http://creativecommons.org/licenses/by-nc/3.0/), permitting all non-commercial use, distribution, and reproduction in any medium, provided the original work is properly cited. 


\title{
Exploring the Factors Affecting Consumer Purchase Behavior during COVID-19: A Case Study of Techno Products in Dhaka City
}

\author{
Takrima Jannat ${ }^{\alpha}$, Syed Abdullah Al Noman ${ }^{\sigma}$, Anika Meher Amin ${ }^{\circ}$, Md. Shafkat Imon Araf ${ }^{\omega}$, \\ Md. Irtija Tahmid Hossain ${ }^{*}$ \& Siha Fatima Hoque ${ }^{\S}$
}

Abstract- Purpose: This paper proposes an exhaustive examination of investigating the variables influencing shopper/consumers' buy conduct during COVID-19 on techno items in Dhaka city. This study intends to investigate the components emerging from vulnerability like Covid pandemic on the customer buy conduct of techno items in Dhaka city.

Methodology: 226 respondents were surveyed using a 19items structured questionnaire. Exploratory Factor Analysis technique was used to identify the significant factors.

Findings: Results demonstrated that five factors, namely, economic fluctuation and technological value chain, ecommerce wave, digital workplace/force, crisis attitude, motivations of changing consumer behavior were found significantly responsible for influencing shopper/consumers' buy conduct during COVID-19 on techno items in Dhaka city.

Practical Implications: Identifying the factors influencing shopper/consumers' buy conduct during COVID-19 on techno items may guide policymakers and the techno industry to undertake necessary actions to overcome the accompanying challenges of the coronavirus pandemic.

Originality: This study is the first attempt to assess the relationship between a pandemic like COVID-19 and consumer behavior during COVID-19 on techno items in Dhaka city.

Keywords: covid-19, consumer behavior, technology industry, economy fluctuation.

Statement of Intended Contribution: The paper is intended to contribute to the technology companies to better understand the impulse purchase behavior of their customers. This paper also gives a unique perspective of how the COVID-19 pandemic has shaped the business industries and the tech-based global village. The paper focuses on studying the viewpoints of

Author $\alpha$ : Bangladesh University of Professionals Address: Kazipara, Mirpur, Dhaka \& Siha Fatima Hoque. e-mail: xtakrima@gmail.com

Author o: Institute: Bangladesh University of Professionals Address: Zia Colony, Dhaka Cantonment.

e-mail: abdullahalnomansyed042@gmail.com

Author p: Bangladesh University of Professionals Address: House\#605, Road \#09, Avenue\#06, Mirpur DOHS, Dhaka.

e-mail: anikameher@gmail.com

Author w: Bangladesh University of Professionals Address: Room no: 202, building: Projonmo, Nirjhar Residential Area, Dhaka Cantonment. e-mail:mdshafkatimonaraf@gmail.com

Author ¥: Bangladesh University of Professionals Address: 79/4, Dhaka Cantonment.e-mail: diptohossain117325@gmail.com

Author \&: Bangladesh University of Professionals Address: 116 no lake circus kolabagan Dhaka.e-mail: sihahoque09@gmail.com the target markets and consumers. The questions and the research address the rapid change in customer behavior and the factors towards the changes. The research addresses that economic fluctuation \& technological value chain have been critical factors behind consumer behavior. Academic marketing discipline's existing knowledge would be enhanced with the paper's information with a unique angle on the technological value chain and the new e-commerce wave. The overpopulated Dhaka city stood still at the beginning of the pandemic, being more derived from working from home situations, online classes, more online shopping, etc. soon leaning into a more technodependent world. The paper focuses on this sudden change and how it affected consumer behavior and increased economic fluctuation in Dhaka. This paper will provide new insights on the changing techno industry in the pandemic period and how the industry will change predominantly. This new insight into the techno industry will be valuable to all firms, policymakers, and business owners. This paper will not only give them insight into how much the industry has changed but will also give them a perception of the consumer's psychologies and motivations for their changing consumer behavior. Our paper would influence policymakers to take into account the critical factors affecting consumer behavior and the impending changes due to the pandemic as well. With a crucial part of our economy that depends on the technological and business industry, we hope to contribute to the economy of Dhaka city as well.

\section{INTRODUCTION}

nitiating in December 2019, in the city of Wuhan in China, an outbreak of the COVID-19 virus drove the world into one of the largest pandemics. Though WHO declared the Pandemic on March 11, 2020. The virus is caused by severe acute respiratory syndrome coronavirus 2 (SARS-CoV-2), which spreads through the respiratory systems very rapidly, becoming very difficult to contain, leading the city and eventually all other countries into lockdown for an undetermined amount of time. After the arrival of 312 citizens of Bangladesh from Wuhan, China and 14days of quarantine, the first case of coronavirus was detected on March 8, 2020. 
According to reports, as of July $8,2020,168,645$ Bangladeshi citizens had been diagnosed positive with the novel Coronavirus. While the number of deaths due to COVID-19 had reached 2,151 by that date. (Bangladesh Preparedness and Response Plan for COVID-19, 2021)

With the ongoing Pandemic and lockdown for a long while, especially in Dhaka due to the large population, the purchase behavior of the city's inhabitants changed noticeably. The techno industry faced significant changes in its sales and customer behavior. With the increased use of techno products and the internet, Dhaka inhabitants increasingly started buying smartphones, tabs, laptops, routers etc. Socialization and communication inclined more to the virtual ways due to the lengthy lockdown, and people relied on video calling to keep in touch with friends and family. In attempts to keep themselves out of boredom, people also increased their video streaming and video gaming times. (Report, 2020).

While there was a significant change in consumer behavior, accelerating the purchase of techno products due to rapid digitalization, the financial strains caused by the Pandemic also decreased the purchase of techno products for many. Unemployment and terminations have caused many people to see buying techno products as a luxury. The usage of techno products significantly increased due to digital commerce. Online shopping, digital workforces, work from home opportunities, online classes, etc., escalated the need and usage of techno products.

The broad objective of this paper is to inspect and study the factors that affected consumer purchase behavior and use of technological products in the capital, Dhaka city. Some of the specific objectives of the paper include studying crisis attitude and change in consumer behavior, investigating the effects of rapid digitalization and analyzing the relationship between the technological value chain and economic fluctuation due to the e-commerce wave.

\section{il. Literature Review}

The covid-19 has shaped our preferences \& even worldwide, the necessary foundation of many aspects has changed. From the economy to even geopolitics, everything has taken a new turn in the crisis. (Aktürk et al., 2020)

The developing Asian countries have been affected by the Pandemic (though lately) in the economic sectors. Mostly the production \& tourism are greatly hampered. India, Bangladesh \& other south Asian countries are also included in this. Developed countries were also affected as they could not manage many of their procurement from the nations. They could import materials earlier at a cheap cost. (Debnath, 2020).
The production or GDP is impended as many of the country's export is affected by Pandemic. As the global supply chain is impeded due to this time, Bangladesh also falls in the queue as it's one of the main drives in the garments industry. The rural economy suffered due to a lack of remittance. For urban people, it is less likely to have continuous fluidity of cash for even covering basic needs \& safety issues. (Amit. 2020) Covid affected $95 \%$ of household's income (Antara, 2020)

But for the City areas, for instance, the capital Dhaka was not affected as the same. Banking sectors, job sectors even start-ups were slowed down, but we saw a great change in the city habitats livelihood behavior. It affected the purchase attitude (Wright \& Blackburn, 2020) of the whole world population. Many fear factors, safety factors have originated that were never seen before. Other important drivers such as social presence, e loyalty have been playing a very significant role. (Addo, Jiaming, Kulbo \& Liangqiang, 2020)

The E-commerce industry had to struggle a lot to gain trust in the customer for a long (ABIR, 2020). Even they were struggling to raise funds were at boom comparing to other start-ups in the pandemic situation, even in our country, except it comes to E-commerce. Pandemic is likely to open a new funnel of business attitude, thus unveiling a new perspective in the behavior of the consumer. (Price water house Coopers. (n. d.).)

This recently emerged trust on the platform implies many things. First of all, a great technological advancement movement \& an extraordinary turn of the event of Dhaka city's people from an analog to technologically oriented consumer behavior. Due to the Pandemic, many curriculums have gone online, such educations, jobs, the usage of technological devices were greater. (Fatema, 2020)

Also, during pandemic increment of broadband internet users is in Dhaka is very significant (from 2.82 million in February to 8.57 million in June). People spend their "leisure" on the internet, playing games (PUBG, for example), surfing randomly on the web. With the shutdown of schools, offices, shops and markets, people have started working from home, passing the time using social media. Students are attending classes over the internet; customers are buying products on ecommerce sites, internet use has gone up (Irani, 2020)

So, the usage of technological devices has increased very rapidly. This means the consumer behavior towards technology is immense. Consumer behavior is a field that draws on different disciplines such as psychology, sociology \& economics to explain the choices a consumer makes. It is the study of individuals and organizations and how they select and use products and services. The study of consumer buying behavior is most important for marketers as they can understand the expectation of the consumers. It 
helps to understand what makes a consumer buy a product. It is important to assess the kind of products liked by consumers to release them to the market. (Solomon, M., Russell-Bennett, R., \& Previte, J. (2012)

Another significant thing that happened is, consumers behavioral pattern is shifting to an "impulsive one." Due to immense technological access \& becoming prone to online shopping, people are most likely making sudden \& unplanned decisions to purchase a product. This effect was most noticed in the mobile system users, individuals who use a mobile phone to shop. It also shows that mobile phone interaction causes them more emotional reactions or attachments, resulting in the purchase. (Zhang, Leng \& Liu, 2020)

Due to Pandemic, we see these kinds of shifting of consumer behavior are very prominent like., Less tolerance for risks \& increment of digitalization. Though consumers were not always satisfied with the quality \& services of the recent Pandemic generated E-commerce boom, due to necessity \& safety issues, the enduring lockdown effect is hindering their natural purchase behavior\& decisions as well. (Sood, 2020). The basic motivation of the behavior results from two main factors, the technology acceptance model (TPA), e.g., Electronic E-commerce ad pushing \& theory of planned behavior. (Jahangir Alam)

From the perspective of digitalization, we now can assume, for different purposes, technological sectors are at their peak in Dhaka. Mobile phone sales have emerged on a large scale. Even new brands like Realme have launched lately \& gained a positive result in Asian countries. (in the South East Asia (SEA) region, growing 141\%) (ADB Briefs, 2020). Though some brands have reported a downfall in sales. Multiple stores were shut down due to the Pandemic. Raw material procurement problem arrived for Mobile companies that assemble the final phone parts. This problem is mainly facing domestic companies like Walton. (Report, 2020)

Recently, both up growing demand \& unstable demand for Mobile phone, varying from brands to brands, are declaring a new consumer behavior cycle towards technological products in the crisis situation. Study shows People willingly intend to cut off the budget of their next phone purchases, but still demanding to purchase it. (Naiya, P. (2020) Even this consumer attitude is shown in other technological products as well. Gaming consoles are pretty stable during the situation. (Liz Lee)

Pre-Covid survey assumed that smart phone consumption is most likely to increase $7 \%$ in the crisis. ("COVID-19 and the technology industry", 2020) But the technology sector's demand fluctuated a lot. One of the reasons is overseas consumption of raw materials is hampered. Also, consumers were very much reactive with the pricing because of the crisis. But forecasting the demand was one of the most challenging issues for this sector amidst this Pandemic. (Kosnac, 2020)

Among all these fluctuations \& turning of events, one thing is for sure that technological product or service industry has immense possibility \& potential \& significant impact on consumer behavior that could have less likely predicted earlier. Experts suggest that it will again flourish at its full extent in no longer time. (Wakabayashi, Nicas, Lohr \& Isaac, 2020)

Development of Hypotheses and Research Framework For the convenience of this study following hypotheses were developed based on the literature review:

H1: Economy fluctuations, new demands significantly affect and bring change in consumer behavior.

H2: Increased sales of technological products \& other value chains.

H3: New E-Commerce platforms and virtual business start-ups significantly affect the sales rate of physical stores.

H4: Increased digital workforce affecting employment rates.

H5: Increased impulsive purchase behavior is seen in customers as a result of crisis attitude.

H6: New motivations of changing consumer behavior considering the new normal. 


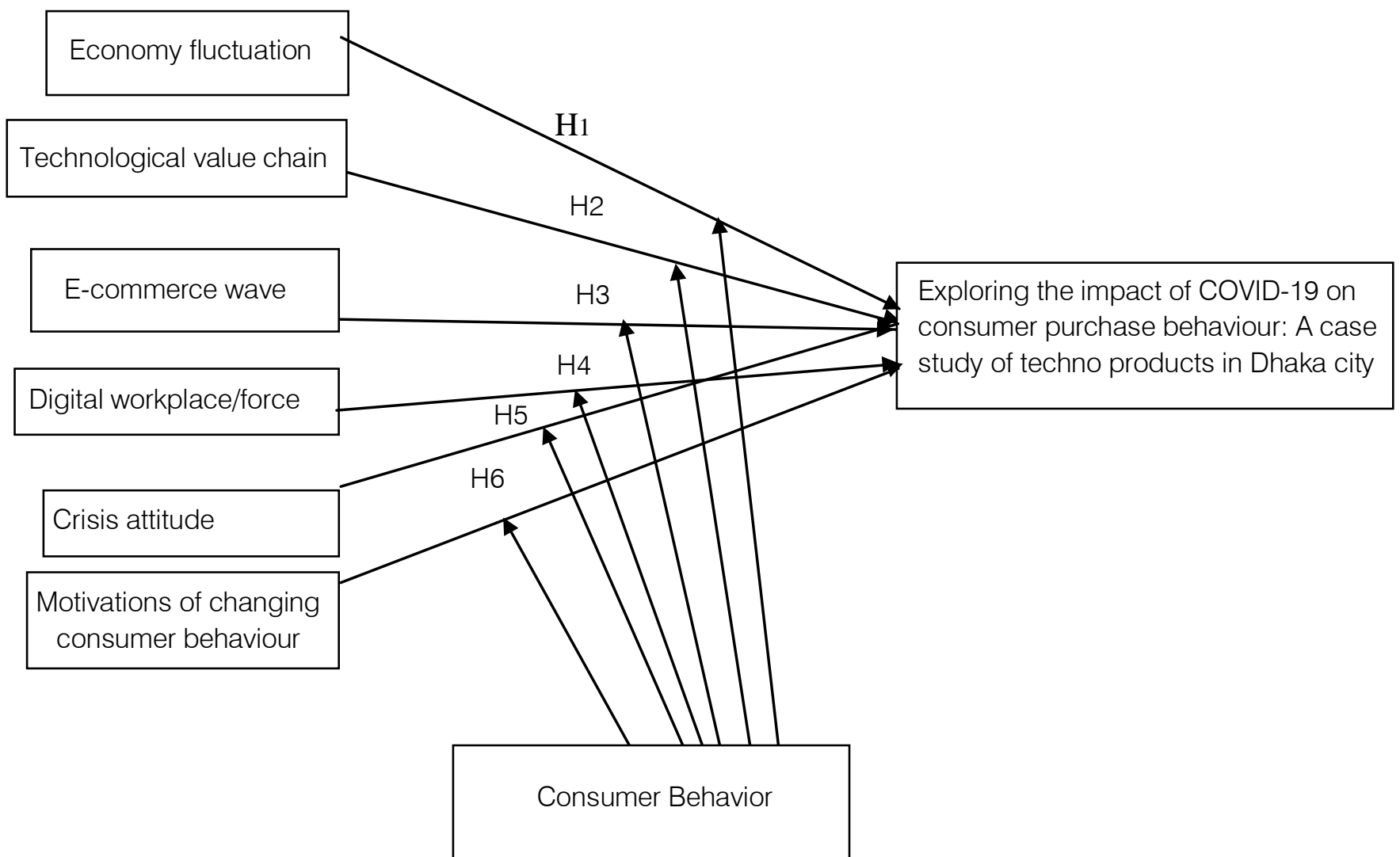

Figure 1: Research Framework

Figure 2: Matrix of independent variables with reference

\begin{tabular}{|c|c|c|c|c|c|}
\hline & $\begin{array}{c}\text { Economy } \\
\text { fluctuation } \\
\text { \& Technological } \\
\text { value chain }\end{array}$ & $\begin{array}{c}\text { E-commerce } \\
\text { wave }\end{array}$ & $\begin{array}{c}\text { Digital } \\
\text { workplac } \\
\text { e/force }\end{array}$ & $\begin{array}{c}\text { Crisis } \\
\text { attitude }\end{array}$ & $\begin{array}{c}\text { Motivations of } \\
\text { changing } \\
\text { consumer } \\
\text { behaviour }\end{array}$ \\
\hline (Aktürk et al., 2020 & $\checkmark$ & & & & $\checkmark$ \\
\hline (Debnath, 2020) & $\checkmark$ & $\checkmark$ & $\checkmark$ & $\checkmark$ & $\checkmark$ \\
\hline Sheth, J. (2020) & $\checkmark$ & $\checkmark$ & $\checkmark$ & $\checkmark$ & $\checkmark$ \\
\hline $\begin{array}{c}\text { Wright \& Blackburn. } \\
\text { (2020) }\end{array}$ & $\checkmark$ & $\checkmark$ & $\checkmark$ & $\checkmark$ & $\checkmark$ \\
\hline $\begin{array}{c}\text { Alam, J. (2020) } \\
\text { Solomon, M., Russell- } \\
\text { Bennett, R., \&Previte, J. } \\
\text { (2012) }\end{array}$ & $\checkmark$ & $\checkmark$ & $\checkmark$ & $\checkmark$ & $\checkmark$ \\
\hline $\begin{array}{c}\text { Solomon, M., Russell- } \\
\text { Bennett, R., \&Previte, J. } \\
\text { (2012) }\end{array}$ & $\checkmark$ & $\checkmark$ & $\checkmark$ & $\checkmark$ & $\checkmark$ \\
\hline $\begin{array}{c}\text { Zhang, W., Leng, X., \& } \\
\text { Liu, S. (2020) }\end{array}$ & $\checkmark$ & $\checkmark$ & $\checkmark$ & $\checkmark$ & $\checkmark$ \\
\hline $\begin{array}{c}\text { Addo, P., Jiaming, F., } \\
\text { Kulbo, N., \&Liangqiang, } \\
\text { L. (2020) }\end{array}$ & $\checkmark$ & $\checkmark$ & $\checkmark$ & $\checkmark$ & $\checkmark$ \\
\hline Naiya. (2020) & $\checkmark$ & $\checkmark$ & $\checkmark$ & $\checkmark$ & $\checkmark$ \\
\hline \begin{tabular}{c} 
Liz Lee. (2019 \\
\hline
\end{tabular} & $\checkmark$ & $\checkmark$ & $\checkmark$ & $\checkmark$ \\
\hline
\end{tabular}




\begin{tabular}{|c|c|c|c|c|c|}
\hline PricewaterhouseCoopers & $\checkmark$ & $\checkmark$ & $\checkmark$ & $\checkmark$ & $\checkmark$ \\
\hline Kosnac, F. (n.d.). & $\checkmark$ & $\checkmark$ & $\checkmark$ & $\checkmark$ & $\checkmark$ \\
\hline Wakabayashi, D. (2020) & & $\checkmark$ & $\checkmark$ & $\checkmark$ & $\checkmark$ \\
\hline Report, S. O. (2020) & & $\checkmark$ & $\checkmark$ & $\checkmark$ & $\checkmark$ \\
\hline Irani, B. (2020) & & $\checkmark$ & $\checkmark$ & $\checkmark$ & $\checkmark$ \\
\hline Fatema, K. (2020) & $\checkmark$ & $\checkmark$ & $\checkmark$ & $\checkmark$ & $\checkmark$ \\
\hline Antara, N. (2020) & $\checkmark$ & $\checkmark$ & $\checkmark$ & $\checkmark$ & $\checkmark$ \\
\hline $\begin{array}{c}\text { The Economic Impact of } \\
\text { the COVID-19 Outbreak } \\
\text { on Developing Asia1. (2020) }\end{array}$ & $\checkmark$ & $\checkmark$ & $\checkmark$ & $\checkmark$ & $\checkmark$ \\
\hline Amit, S. (2020) & $\checkmark$ & $\checkmark$ & $\checkmark$ & $\checkmark$ & $\checkmark$ \\
\hline
\end{tabular}

\section{Research Methodology}

\section{a) Sample and Procedures}

The respondents of our study are mainly tech consumers of different walks of life who bought /consumed products \& mostly tech services in the time of covid-19. We made a questionnaire and collected data from our respondents. The sample of the study was determined by the followed formula suggested by Yamane (1967).

$$
\mathrm{n}=\mathrm{N} / 1+\mathrm{N}(e) 2
$$

Where, $\mathrm{n}=$ Sample Size, $\mathrm{N}=$ Population size, $\mathrm{e}=$ Level of Precision, in calculating the number of samples the following assumptions were made to determine, $n=226$ if Population Size is more than 58,000 ; the level of precision is $7 \%$.

The questionnaires were filled by 226respondents of different age groups of people who had to buy or consume tech products/services to work from home, to attend online classes, to communicate

\begin{tabular}{|c|c|c|c|}
\hline \multicolumn{4}{|c|}{ Case Processing Summary } \\
\hline & & $\mathrm{N}$ & $\%$ \\
\hline \multirow{3}{*}{ Cases } & Valid & 226 & 100.0 \\
\hline & Excluded $^{a}$ & 0 & .0 \\
\hline & Total & 226 & 100.0 \\
\hline
\end{tabular}

with their close ones from home and for entertainment purposes. To collect data for this research structured survey questionnaires were distributed online among respondents living mostly in Dhaka city and a few living in the suburbs.

\section{b) Participants}

Out of 226 tech consumers, $4.01 \%$ aged between Below 20 Years, followed by 20-30 years (90.62\%), 30-40 years (3.57\%), 40-50 years (1.33\%), and 50 or above $(0.44 \%)$. However, most of the youth-centric respondent only $8.07 \%$ were married. Male-female ratio is $34.08 \%$ to $65.47 \%$, while $0.44 \%$ preferred not to say. (Appendix 1)

\section{c) Reliability}

Reliability is defined as the consistency across items like the internal consistency of the variables used in the study. This study shows that the reliability score (Cronbach's Alpha) is at the acceptable limit (0.689) (Nunnally, 1978)

\begin{tabular}{|c|c|c|}
\hline \multicolumn{3}{|c|}{ Reliability Statistics } \\
\hline & $\begin{array}{c}\text { Cronbach's } \\
\text { Alpha Based } \\
\text { Alpha }\end{array}$ & \\
& $\begin{array}{c}\text { on } \\
\text { Standardized } \\
\text { Items }\end{array}$ & \\
\hline .689 & .741 & 19 \\
\hline
\end{tabular}

Figure 3: Reliability test

\section{d) Questionnaire design}

The structured questionnaire by Dabholker (1996) was used to collect information from literature review on the factors fluctuating consumer behavior because of Covid-19. All statements in the questionnaire were measured on five-point scale ranging from 1 to 5 1 being strongly agree and 5 being strongly disagree.
One of the relative advantages of using this scale is its suitability for the applications of multifarious statistical tools used in marketing and social research study (Malhotra, 1999). 
Figure 4: Survey questionnaire

\begin{tabular}{|c|c|c|c|c|c|c|}
\hline Items & Statement & 1 & 2 & 3 & 4 & 5 \\
\hline \multicolumn{7}{|c|}{ Economy Fluctuation Technological value chain (EF) } \\
\hline EF1 & $\begin{array}{l}\text { I believe that technological devices help us to stay connected with the world } \\
\text { during this Pandemic }\end{array}$ & & & & & \\
\hline EF2 & $\begin{array}{l}\text { I used to take services using digital devices or technology (internet, for } \\
\text { example) before Pandemic. }\end{array}$ & & & & & \\
\hline EF3 & $\begin{array}{l}\text { A labourer who earns a very little amount of money daily suffered a lot due to } \\
\text { this pandemic situation }\end{array}$ & & & & & \\
\hline EF4 & I am pretty much dependent on technology because of lockdown. & & & & & \\
\hline EF5 & I think the Covid situation has created new demand in the economy. & & & & & \\
\hline EF6 & I think digital workplaces have a direct relation with technological devices. & & & & & \\
\hline EF7 & I think digital devices have fulfilled many utilities during this Pandemic. & & & & & \\
\hline \multicolumn{7}{|c|}{ New motivation of Changing behavior (MCB) } \\
\hline MCB1 & $\begin{array}{l}\text { Have you bought any technological product/accessory (smart phone, } \\
\text { headphones, laptops) during the Pandemic which you wouldn't consider } \\
\text { buying if the Pandemic was non-existent? }\end{array}$ & & & & & \\
\hline MCB2 & $\begin{array}{l}\text { I think the absence of technological devices wouldn't motivate me much to } \\
\text { shop or doing other things online. }\end{array}$ & & & & & \\
\hline MCB3 & $\begin{array}{l}\text { I think spending too much time online has motivated me in any purchase in } \\
\text { this quarantine. }\end{array}$ & & & & & \\
\hline MCB4 & $\begin{array}{l}\text { E-commerce usage wouldn't be possible during the Pandemic if there were } \\
\text { not constant growth of technological uses. }\end{array}$ & & & & & \\
\hline \multicolumn{7}{|c|}{ E-Commerce wave } \\
\hline ECW1 & I have been much prone to online shopping during this Pandemic. & & & & & \\
\hline ECW2 & I think online activities increased my technological device usage notably. & & & & & \\
\hline ECW3 & $\begin{array}{l}\text { Safety measures played an important role for me to select a particular e- } \\
\text { commerce website or online shop. }\end{array}$ & & & & & \\
\hline \multicolumn{7}{|c|}{ Novelty of digital workforce \& environment } \\
\hline DG1 & $\begin{array}{l}\text { Have you bought any technological product/accessory (smart phone, } \\
\text { headphones, laptops) during the Pandemic which you wouldn't consider } \\
\text { buying if the Pandemic was non-existent? }\end{array}$ & & & & & \\
\hline DG2 & $\begin{array}{l}\text { Have you experienced "digital workplace" activity in this Pandemic? For } \\
\text { example: doing offices, attending classes from home etc. }\end{array}$ & & & & & \\
\hline DG3 & $\begin{array}{l}\text { I Have relied more on spending time online than going out. Thus, I took } \\
\text { relative actions regarding it like buying a technological product or have } \\
\text { broadband in your house. }\end{array}$ & & & & & \\
\hline \multicolumn{7}{|c|}{ Crisis Attitude } \\
\hline CA1 & I believe that people have faced a financial crisis in this Pandemic. & & & & & \\
\hline \multicolumn{7}{|c|}{ Dependent Variable (DP) } \\
\hline DP1 & $\begin{array}{l}\text { I think some factors are affecting consumer purchase behaviour during } \\
\text { COVID-19 to buy or connect more with techno products. }\end{array}$ & & & & & \\
\hline
\end{tabular}

$1=$ Strongly Agree

$2=$ Agree

$3=$ Neutral

$4=$ Disagree

$5=$ Strongly Disagree

\section{Data Analysis Technique}

In descriptive analysis, demographical factors for example gender, age, profession were analyzed. Exploratory Factor Analysis (EFA) was used to analyze the data from descriptive data. The survey was conducted in January2021. Using SPSS, principal component analysis with a varimax rotation was conducted to analyze the survey data., Multiple Regression was conducted using SPSS to recognize the relationships between the significant factors and the dependent and independent variables.

\section{Results and Discussions}

\section{a) Results of Factor Analysis}

The results of factor analysis show that all the variables concerning "Exploring the impact of COVID-19 on consumer purchase behavior: A case study of techno products in Dhaka city." 
Are very high, indicating the variables are important in this area of study (Appendix 2). Figure 5 shows the critical factors for the impact of consumer behavior towards techno products. It shows that factors such as Economy fluctuation \& Technological value chain, E-commerce wave, Digital workplace/force, Crisis attitude, Motivations of changing consumer behavior are the critical factors for the impact of consumer behavior towards techno products. The Variance of factor named Economy Fluctuation \& Technological value chain is the highest $(23.109 \%)$ followed by Motivations of changing consumer behavior (9.887\%), E-Commerce wave (7.811\%), Novelty of digital workforce \& environment $(6.536 \%)$, Crisis Attitude (5.782\%). The total Variance of the data set is $53.125 \%$ indicates that a major portion of the data set is included in the analysis.

Figure 5: Total Variance Explained

\begin{tabular}{|c|c|c|c|}
\hline & \multicolumn{3}{|c|}{ Initial Eigenvalues } \\
\cline { 2 - 4 } & Total & \% of Variance & Cumulative \% \\
\hline $\begin{array}{c}\text { Economy Fluctuation \& } \\
\text { Technological value chain }\end{array}$ & 4.160 & 23.109 & 23.109 \\
\hline $\begin{array}{c}\text { Motivations of changing } \\
\text { consumer behaviour }\end{array}$ & 1.780 & 9.887 & 32.996 \\
\hline E-Commerce wave & 1.406 & 7.811 & 40.807 \\
\hline $\begin{array}{c}\text { The Novelty of the digital } \\
\text { workforce \& environment }\end{array}$ & 1.176 & 6.536 & 47.343 \\
\hline Crisis Attitude & 1.041 & 5.782 & 53.125 \\
\hline
\end{tabular}

Principal Component Analysis (PCA) and the Varimax Rotation approach were applied to derive the independent variables. Given the sample size of 226, standardized factor loadings of 0.40 and higher for evaluative purposes are considered significant in this research. A five-factor structure was developed based on the eigen values of the factors (above 1).

This paper adopted four broadly recognized hypotheses for Exploratory Factor Analysis (EFA) (Hair et al., 1998; Andy, 2000): (i) $\mathrm{KMO}$ sampling adequacy value above 0.5 .

(ii) The minimum eigen value for each factor is 1 .

(iii) The factor loadings of each measured variable are above 0.40 .

(iv) The use of varimax rotation is the most used orthogonal rotation technique that helps to achieve a simplified factor model. (Andy, 2000).

Figure 6: KMO and Bartlett's Test

\begin{tabular}{|l|c|c|}
\hline \multicolumn{2}{|c|}{ Kaiser-Meyer-Olkin Measure of Sampling Adequacy. } & .795 \\
\hline \multirow{3}{*}{ Bartlett's Test of Sphericity } & Approx. Chi-Square & 782.582 \\
\cline { 2 - 3 } & $\mathrm{df}$ & 153 \\
\cline { 2 - 3 } & Sig. & .000 \\
\hline
\end{tabular}

Factor analysis can only be conducted if the Kaiser-Meyer-Olkin (KMO) and Bartlett's test of Sphericity value of the dataset are significant. Hair et al., (2010). Figure 6 shows that Kaiser's measures of sampling adequacy of this research are 0.795 , and Bartlett's test of sphericity is significant $(p=0.000)$, which indicates the viability of factor analysis in our research.

Figure 7: Rotated Component Matrix ${ }^{a}$ Component

\begin{tabular}{|l|c|c|c|c|c|}
\hline & 1 & 2 & 3 & 4 & 5 \\
\hline & \multicolumn{2}{|c|}{$\begin{array}{l}\text { Factor 1: Economy Fluctuation \& } \\
\text { Technological value chain }\end{array}$} \\
\hline $\begin{array}{l}\text { I believe that technological devices help us to stay connected with the } \\
\text { world during this Pandemic }\end{array}$ & .759 & & & & \\
\hline $\begin{array}{l}\text { I used to take services using digital devices or technology (internet, for } \\
\text { example) before Pandemic. }\end{array}$ & .651 & & & & \\
\hline $\begin{array}{l}\text { A laborer who earns a very little amount of money daily suffered a lot } \\
\text { due to this pandemic situation }\end{array}$ & .635 & & & & \\
\hline I am pretty much dependent on technology because of lockdown. & .613 & & & & \\
\hline I think the Covid situation has created new demand in the economy. & .578 & & & & \\
\hline
\end{tabular}




\begin{tabular}{|c|c|c|c|c|c|}
\hline $\begin{array}{l}\text { I think digital workplaces have a direct relation with technological } \\
\text { devices. }\end{array}$ & .562 & & & & \\
\hline I think digital devices have fulfilled many utilities during this Pandemic. & .463 & & & & \\
\hline \multicolumn{6}{|c|}{ Factor 2: New motivation of Changing behaviour } \\
\hline $\begin{array}{l}\text { Have you bought any technological product/accessory (smartphone, } \\
\text { headphones, laptops) during the Pandemic which you wouldn't } \\
\text { consider buying if the Pandemic was non-existent? }\end{array}$ & & .714 & & & \\
\hline $\begin{array}{l}\text { I think the absence of technological devices wouldn't motivate me } \\
\text { much to shop or doing other things online. }\end{array}$ & & 628 & & & \\
\hline $\begin{array}{l}\text { I think spending too much time online has motivated me in any } \\
\text { purchase in this quarantine. }\end{array}$ & & .524 & & & \\
\hline $\begin{array}{l}\text { E-commerce usage wouldn't be possible during the Pandemic if there } \\
\text { were not constant growth of technological uses. }\end{array}$ & & .515 & & & \\
\hline \multicolumn{6}{|l|}{ Factor 3: E-Commerce wave } \\
\hline I have been much prone to online shopping during this Pandemic. & & & .762 & & \\
\hline $\begin{array}{l}\text { I think online activities increased my technological device usage } \\
\text { notably. }\end{array}$ & & & .736 & & \\
\hline $\begin{array}{l}\text { Safety measures played an important role for me to select a particular } \\
\text { e-commerce website or online shop. }\end{array}$ & & & .538 & & \\
\hline \multicolumn{6}{|c|}{ Factor 4: Novelty of digital workforce \& environment } \\
\hline $\begin{array}{l}\text { Have you bought any technological product/accessory (smartphone, } \\
\text { headphones, laptops) during the Pandemic which you wouldn't } \\
\text { consider buying if the Pandemic was non-existent? }\end{array}$ & & & & .784 & \\
\hline $\begin{array}{l}\text { Have you experienced "digital workplace" activity in this Pandemic? For } \\
\text { example: doing offices, attending classes from home etc. }\end{array}$ & & & & .770 & \\
\hline $\begin{array}{l}\text { I Have relied more on spending time online than going out. Thus, I took } \\
\text { relative actions regarding it like buying a technological product or have } \\
\text { broadband in your house. }\end{array}$ & & & & -.423 & \\
\hline \multicolumn{6}{|l|}{ Factor 5: Crisis Attitude } \\
\hline I believe that people have faced a financial crisis in this Pandemic. & & & & & .762 \\
\hline \multicolumn{6}{|c|}{ Extraction Method: Principal Component Analysis. Rotation Method: Varimax with Kaiser Normalization. } \\
\hline erged in $5 \mathrm{i}$ & & & & & \\
\hline
\end{tabular}

The results of exploratory factor analysis show that all the variables concerning the critical factors for the impact of consumer behavior towards techno

products in Dhaka city have high commonalities indicating the variables are important in this study (Figure 7).

\section{Results of Regression Analysis}

The model summary shows that the $\mathrm{R}$ square value of the model is 0.251 (Figure 8 ).

Figure 8: Model Summary ${ }^{\text {b }}$

\begin{tabular}{|l|c|c|c|c|c|c|c|c|c|}
\hline \multirow{2}{*}{$\begin{array}{c}\text { Mo } \\
\text { del }\end{array}$} & $\mathrm{R}$ & $\begin{array}{c}\mathrm{R} \\
\text { Square }\end{array}$ & $\begin{array}{c}\text { Adjusted } \\
\text { R Square }\end{array}$ & $\begin{array}{c}\text { Std. Error } \\
\text { of the } \\
\text { Estimate }\end{array}$ & $\begin{array}{c}\text { R Square } \\
\text { Change }\end{array}$ & $\begin{array}{c}\mathrm{F} \\
\text { Change }\end{array}$ & $\mathrm{df1}$ & $\mathrm{df2}$ & $\begin{array}{c}\text { Sig. F } \\
\text { Change }\end{array}$ \\
\hline 1 & $.501^{\mathrm{a}}$ & .251 & .234 & .771 & .251 & 14.744 & 5 & 220 & .000 \\
\hline
\end{tabular}




\begin{tabular}{|l|c|c|c|c|c|c|}
\hline \multicolumn{2}{|c|}{ Model } & $\begin{array}{c}\text { Sum of } \\
\text { Squares }\end{array}$ & df & $\begin{array}{c}\text { Mean } \\
\text { Square }\end{array}$ & F & Sig. \\
\hline \multirow{3}{*}{1} & Regression & 43.833 & 5 & 8.767 & 14.744 & $.000^{\mathrm{b}}$ \\
\cline { 2 - 7 } & Residual & 130.809 & 220 & .595 & & \\
\cline { 2 - 7 } & Total & 174.642 & 225 & & & \\
\hline $\begin{array}{l}\text { a. Dependent Variable: I think some factors affect consumer purchase } \\
\text { behavior during COVID-19 to buy or connect more with techno products. }\end{array}$ \\
\hline $\begin{array}{l}\text { b. Predictors: (Constant), REGR factor score } 5 \text { for analysis 1, REGR factor } \\
\text { score 4 for analysis 1, REGR factor score } 3 \text { for analysis 1, REGR factor } \\
\text { score 2 for analysis 1, REGR factor score } 1 \text { for analysis 1 }\end{array}$ \\
\hline
\end{tabular}

Figure 9: ANOVA $^{\text {a }}$

This study identified five factors related to the impact of consumer behavior of Dhaka city towards techno products. Such as Economy fluctuation \& technological value chain, Motivations for changing behavior, E-commerce wave, Novelty of digital workforce \& environment, Crisis attitude (Figure 10) The established regression model for the study using the standardized coefficients is:

$$
\mathrm{Y}=4.073+.31 \mathrm{X}_{1}+.36 \mathrm{X}_{2}+.11 \mathrm{X}_{3}-.106 \mathrm{X}_{4}+.043 \mathrm{X}_{5}
$$

a. Dependent Variable: I think some factors are affecting consumer purchase behavior during COVID-19 to buy or connect more with techno products.

\section{Figure 10: Coeffcients ${ }^{\text {a }}$}

Individual critical factors like Economy fluctuation \& technological value chain and New motivations for changing behavior are significant factors for the impact of consumer behavior towards techno products in Dhaka city. The factors such as Ecommerce wave, Novelty of digital workforce \& environment, Crisis attitude are not found significant in this study (Figure 10).

\section{Vil. Recommendation \& Conclusion}

The study is the first to correlate consumer behavior towards techno products during recent Covid pandemic. This study finds two significantly related factors to the subject among the extracted five factors. Those are Economy fluctuation \& technological value chain and New motivations for changing behavior. We believe this study has a great potential for the technological companies that provides tech products \& services to understand the impulse purchase behavior of the target consumer from a unique angle. This paper can give us an idea how pandemic in digital world not only shapes consumer behavior towards the necessary livelihood or health issues but also affect a bourgeoning tech-based global village very empirically.

\section{AcKnOWledgement}

The research has been completed due to the kind support of many. We would like to thank Lecturer Takrima Jannat ma'am for working with us and guiding us through every step. We would also like to thank all the respondents who were cooperative and helped us by answering the questions of questionnaire. It was indeed a great experience for us. Above all we would like to thank the Great Almighty, the author of knowledge and wisdom for his countless mercy.

\section{References Références Referencias}

1. Addo, P. C., Jiaming, F., Kulbo, N. B., \& Liangqiang, L. (2020). COVID-19: fear appeal favouring purchase behaviour towards personal protective equipment. The Service Industries Journal, 40(7-8), 471-490. 
2. Aktürk, Ş., Arnold, M., Başbay, M., Birgel, S., Cherkaoui, T., \& Mohydin, R. (2020). The Covid-19 Pandemic: A Global Outlook.

3. Alam, J. (2020). Buying Behavior under Coronavirus Disease (COVID-19) Pandemic Situation: An Online Perspective Case in Bangladeshi Shoppers. Chinese Business Review, 19(3), 82-90.

4. Amit, S. (2020, August 1). Coronavirus and Impact on the Bangladesh Economy: Assessing the Damage of the Black Swan of 2020. The Asia-Pacific Journal: Japan Focus. https://apjjf.org/2020/15/ Amit.html

5. Andy, F. (2000). Discovering statistics using spss for windows: Advanced techniques for the beginner.

6. Antara, N. (2020, June 20). Covid-19 impacts 95\% households' income. Dhaka Tribune. https://www.d hakatribune.com/health/coronavirus/2020/06/20/cov id-19-impacts-95-households-income.

7. Bangladesh Preparedness and Response Plan for COVID-19, 2021. Government of the People's Republic of Bangladesh. http://www.mohfw.g v.bd/index.php?option $=$ com_docman\&task $=$ doc $\_d$ ownload\&gid $=23359$ \&lang $=$ en

8. Debnath, S. (2020). Impact of COVID-19 on Consumer Purchase Behaviour in Retail SectorStudy Based in Kolkata Area. Available at SSRN 3634598.

9. Fatema, K. (2020, August 29). Weak infrastructure denies benefit of online classes to many. The Business Standard. https://tbsnews.net/banglades h/education/online-class-where-education-hasturned-misery-125077

10. Hair, J. F., Anderson, R. E., Tatham, R. L., \& Black, W. C. (1998). Multivariate data analysis. 1998. Upper Saddle River.

11. Irani, B. (2020, September 9). Broadband internet services surge in Covid-19 Pandemic. Dhaka Tribune. https://www.dhakatribune.com/business/c ommerce/2020/09/09/broadband-internet-servicessurge-in-covid-19-pandemic

12. Kosnac, F. (n.d.). How Coronavirus Is Affecting the Technology Industry. EisnerAmper. https://www .eisneramper.com/coronavirus-te-blog-0320/

13. Liz Lee. (2019, September 12). Game Console Market Set for a Leap in 2020. Counterpoint Research. https://www.counterpointresearch.com/ game-console-market-set-leap-2020/

14. Malhotra, N. K. (1999). Marketing Research: an applied orientation. London: Prentice-Hall International.

15. Naiya. (2020, September 2). One in Every Three Smartphone Users Will Cut Spending by $20 \%$ or More. Counterpoint Research. https://www.count erpointresearch.com/smartphone-users-cut-
spending-nextsmartphone/\#:\%7E:text=One\%20in \%20three\%20respondents\%20to,by\%20the\%20COV VID\%2D19\%20crisis

16. Nunnally, J. (1978). C. (1978). Psychometric theory, 2.

17. PricewaterhouseCoopers. (n.d.). COVID-19 and the technology industry. PwC. Retrieved October 24, 2020, from https://www.pwc.com/us/en/librar y/c ovid-19/coronavirus-technology-impact.html

18. Report, S. O. (2020, May 27). Amid the Covid-19 Pandemic, smartphones take a blow. The Daily Star. https://www.thedailystar.net/amid-the-covid-19-pand emic-smartphones-take-blow-1905835

19. Sheth, J. (2020). Impact of Covid-19 on Consumer Behavior: Will the Old Habits Return or Die? Journal of Business Research.

20. Solomon, M., Russell-Bennett, R., \& Previte, J. (2012). Consumer behaviour. Pearson Higher Education AU.

21. The Economic Impact of the COVID-19 Outbreak on Developing Asia1. (2020, March 6). Www.Adb.Org. https://www.adb.org/sites/default/files/publication/5 71536/adb-brief-128-economic-impact-covid19-dev eloping-asia.pdf

22. Wakabayashi, D. (2020, March 24). Big Tech Could Emerge From Coronavirus Crisis Stronger Than Ever. Https:/Mww.Nytimes.Com/\#publisher. https://www.nytimes.com/2020/03/23/technology/co ronavirus-facebook-amazon-youtube.html

23. Wright \& Blackburn. (2020). How COVID-19 will permanently change consumer behaviour, Fastchanging consumer behaviours influence the future of the CPG industry. Retrieved October 20, 2020, from https://www.accenture.com/ acnmedia/PDF123/Accenture-COVID19-Pulse-Survey-Research-Po V.pdf

24. Zhang, W., Leng, X., \& Liu, S. (2020). Research on mobile impulse purchase intention in the perspective of system users during COVID19. Personal and Ubiquitous Computing, 1-9. 


\section{APPENDIX 1}

Respondent's Profile

\begin{tabular}{|c|c|c|c|c|}
\hline & Frequency & Percent & Valid Percent & Cumulative Percent \\
\hline \multicolumn{5}{|c|}{ Age } \\
\hline Below 20 Years & 9 & 4.01 & 4.01 & 4.01 \\
\hline 20-30 years & 203 & 90.62 & 90.62 & 94.63 \\
\hline $30-40$ years & 8 & 3.57 & 3.57 & 98.2 \\
\hline $40-50$ years & 3 & 1.33 & 1.33 & 99.53 \\
\hline 50 or above & 1 & 0.44 & 0.44 & 100 \\
\hline \multicolumn{5}{|c|}{ Gender } \\
\hline Female & 76 & 34.08 & 34.08 & 34.08 \\
\hline Male & 146 & 65.47 & 65.47 & 99.55 \\
\hline Prefer not to say & 1 & 0.44 & 0.44 & 100 \\
\hline \multicolumn{5}{|c|}{$\begin{array}{l}\text { Marital } \\
\text { Status }\end{array}$} \\
\hline Married & 18 & 8.07 & 8.07 & 8.07 \\
\hline Unmarried & 205 & 91.92 & 91.92 & 100 \\
\hline
\end{tabular}

